Original research article

\title{
How the length of time spent on the streets impacts adjustment to homelessness
}

\author{
Marie Vágnerová ${ }^{1}$, Jakub Marek ${ }^{1}$, Ladislav Csémy ${ }^{1,2}$ * \\ ${ }^{1}$ Charles University, Hussite Theological Faculty, Prague 4, Czech Republic \\ ${ }^{2}$ National Institute of Mental Health, Klecany, Czech Republic
}

\section{Abstract}

Background: The length of time spent on the street influences the degree of adjustment to homelessness. Over the years spent sleeping rough, homeless people gradually lose the ability to control their lives and their return to mainstream society becomes less and less likely. Goal: The aim of the study was to discover whether and how men who have been sleeping rough for more than ten years differ from those who have been homeless for four years or less.

Methods: The research was based on a narrative analysis of in-depth interviews focused on the respondent's entire life story, i.e. their childhood, adolescence, and the period of adulthood preceding homelessness. The group under examination comprised 51 homeless men aged 37-54.

Results: Men who have been sleeping rough for more than ten years grew up in a problematic family or in an institution and acquired only a rudimentary education. From the start they had problems at work. They tend to have high-risk personality traits and often a personality disorder. Early in life they had problems with alcohol or drugs. They are reckless - even when it comes to the law - and often commit crime.

Conclusions: The length of time a person has been homeless for is an important factor in relation to social prevention. It is clear that the longer a person is homeless, the worse their chances of being reintegrated into mainstream society.
\end{abstract}

Keywords: Homeless people; Life course; Narrative analysis; Risk factors; Social adjustment

\section{Introduction}

The length of time spent on the street influences the degree of adjustment to homelessness (Auerswald and Eyre, 2002; Boydell et al., 2000; Farrington and Robinson, 1999; Janebová, 1999; Johnson and Chamberlain, 2008; Vágnerová et al., 2013). During the first year, people become acquainted with the conditions of homelessness. Their main priority is survival and coping with the burdens they face. Their self-image has not changed because they are convinced that this is only a temporary situation. Over the next two years they begin to accept the new situation and acquire the skills that are essential on the street. They gradually become used to a lifestyle without any great demands, focus on the present, and no longer dwell upon returning to mainstream society or postpone such a return indefinitely. They are more experienced and know that life on the street is difficult and that the interpersonal relationships that exist there are far from idyllic. They tend to distinguish themselves from typical homeless people and, though they have not yet fully accepted their identity as being someone without a home, they are aware that they have changed.
After several years, the habits and lifestyle of a homeless person have taken root, along with a change in self-esteem. They gradually lose the ability to control their lives, and their return to mainstream society becomes less and less likely. In general, the longer someone is sleeping rough, the more they change. Their competencies change and the negative consequences of risky activities (drug and alcohol addiction) intensify. Sometimes their state of health deteriorates or another form of social decline takes place (a prison term or an increase in personal debt). The awareness of one's own decline and the disapproval from the majority society, as well as the lack of a functioning background that could support them, complicates any possible resolution of their situation. They are part of the homeless community and have no other friends or acquaintances. They now clearly identify with other homeless people. They know that they have changed for the worse and that they are unacceptable in the eyes of society, but they are no longer willing or able to change this state of affairs. They are now resigned to their fate and don't wish to face up to problems that appear insoluble (debt repayment or abstinence). They reject any plan that would require them to exert more effort, and their de-socialisation and personality disintegration continues

\footnotetext{
* Author for correspondence: Ladislav Csémy, National Institute of Mental Health, Topolová 748, 25067 Klecany, Czech Republic; e-mail: csemy@nudz.cz http://doi.org/10.32725/kont.2020.014

Submitted: 2019-09-02 • Accepted: 2020-04-06 • Prepublished online: 2020-04-20 
especially if they have been using alcohol or drugs for a longer period of time.

There can be a relationship between the length of time spent sleeping rough and how young a person was when they became homeless. What this means is that, as a young adult, such a person has already had problems that they were unable to resolve and did not have anyone who was willing and able to help. During the course of their life on the street it is not only socially undesirable attitudes and habits that are reinforced; the personality traits that led to this person becoming homeless in the first place are intensified. The effect of all of this is to reduce their chances of returning to society.

\section{Study aim}

The aim of the study was to explore whether and how men who have been sleeping rough for more than ten years differ from those who have been homeless for four years or less. If prevention is to be made more effective, we need to know how these people were living prior to becoming homeless, how they spent their childhood, what kind of education they have received, and whether they are able to find a job and to work systematically, maintain a partnership and care for their children. There may be a difference between the two groups in respect of the degree of alcohol and drug use, criminal tendencies, and the frequency and seriousness of psychological disorders and mental health issues.

\section{Materials and methods}

\section{Data sources}

The research was based on an analysis of in-depth interviews held from June 2016 to May 2017. In order to acquire information we used a structured interview. The interview touched on the respondent's childhood, adolescence, and the period of adulthood preceding homelessness. Each interview was recorded with the consent of the respondent and later transcribed into electronic text file. The analytic induction method was used to identify major categories. This method is based on the principle of repetition and a constant comparative strategy (Mabhala et al., 2016; Osborn and Smith, 2008).

\section{Sample}

The group under examination comprised 51 homeless men aged 37-54. The first subgroup consisted of 29 men who have been sleeping rough for 10-21 years. Their average age is 47.2 $(S D=5.24)$ and they have been sleeping rough from an average age of $31.4(S D=5.41)$. The second group contains 22 men who have been homeless for four years or less. Their average age is 44.7 years $(S D=5.41)$ and they have been sleeping rough from an average age of $42.5(S D=5.85)$. All subjects in this study fulfilled the conceptual category of roofless persons or people in accommodation for the homeless based on European Typology of Homelessness and Housing Exclusion (Amore et al., 2011).

\section{Presentation of the results}

Qualitative analyses led to ten major categories or domains which are presented in the results section. Within each domain the results of the qualitative analyses of two studied subsamples are shown with short domain-relevant comments based on international and domestic literature. Descriptive statistics of differences between subgroups in frequencies of responses are added to each domain as well.

\section{Results}

\section{Evaluation of childhood and the functioning of the family of orientation}

The families of orientation in which current homeless people grew up differ. Some of our cohort grew up in a surrogate family, others in an institution because their biological parents were unable to look after them. Various studies (Brown et al., 2016; Caton et al., 2006; Cauce et al., 2000; Ferguson, 2009; Mabhala et al., 2016; Tyler, 2006; Vágnerová et al., 2013; Zugazaga, 2004) confirm that people who sleep rough from a young age more often come from families that did not provide a safe and secure background. The parents drank to excess and spent periods in prison, and sometimes suffered mental health issues or personality disorders and were unable to cope with their own lives - let alone those of their children. Inherited traits might also play a role.

Homeless men have different opinions regarding their childhood. Of our respondents who had been sleeping rough for ten years or more, only $35 \%$ had had an acceptably functional family, while the remaining $65 \%$ had grown up in a problematic family or spent some of their childhood in an institution. The opposite applied in men who had been sleeping rough for four years or less, $67 \%$ of whom stated that they had had a functional family until their adolescence and only $33 \%$ of whom did not. This difference of opinion regarding a respondent's childhood is statistically significant $\left(\chi^{2}=4.27\right.$, d.f. $=1$, $P=0.039$ ). We may therefore assume that a person's childhood influences not only the risk of becoming homeless but also the period of time they spend homeless.

Most of our respondents who had been sleeping rough for four years or less had a relatively problem-free childhood. Martin (51): "I had a normal family. There were two children, me and my sister... everything was ok, my childhood was idyllic" (Jan, 51): "I had a good childhood, my family was complete and I had one brother." Neither of these men was addicted to alcohol or drugs and neither had ever been to prison.

Homeless men who have been living on the street for ten years or more say theirs was a problematic family. The father was most often the source of problems. He was often reported as being an alcoholic, had been involved in criminal activity, and behaved aggressively towards the family. Karel (52), who has been sleeping rough for 17 years and is alcohol dependent like his father, says: "Dad was an alcoholic who drank himself to death. He moved out and then I never saw him again. I don't even know when he died. I had a terrible relationship with him because he was always shouting at Mum or trying to hit her."

\section{Education and professional qualifications}

Education means little to many homeless people. This is because of their dysfunctional family and lack of motivation. A dysfunctional family and uneducated parents did not represent a desirable model for the children. They were uninterested in preparing for a profession or even attending school. According to Prudký (2015), 34\% of homeless people have only a primary education, and this figure is $31 \%$ according to Brown et al. (2016), which corresponds to our findings. People with low educational achievements and no qualifications are more at threat of becoming homeless (Rank and Williams, 2010).

Of the men sleeping rough for ten years or more, $48 \%$ had a primary education, $42 \%$ had been apprentices, and $10 \%$ had passed their baccalaureate or had been to university. The opposite applied in the case of men who had been sleeping rough 
for four years or less, of whom $24 \%$ had only a primary education, $38 \%$ had been apprentices, and $38 \%$ had been to secondary school or university. This difference is statistically significant $\left(\chi^{2}=6.59\right.$, d.f. $=2, P=0.037$. It is clear that the lack of an education increases both the risk of homelessness and the period of time spent homeless. A lack of qualifications leads to an inability to find work and in holding down a job.

\section{Work performed before a person becomes homeless}

Laziness, irresponsibility and a lack of any kind of work ethic may be manifest in homeless people. Given that they became homeless while adults, most previously had a job somewhere. Prior to becoming homeless, $21 \%$ of our respondents who have been sleeping rough for ten years and more had worked for a long time (at least five years). The remaining $79 \%$ had only worked occasionally and had had periods of work interrupted by time spent in prison. Half of the men (52\%) who have been sleeping rough for four years or less had worked before becoming homeless, while $48 \%$ had only participated in voluntary work and temporary jobs. The difference between the groups is statistically significant: $\chi^{2}=6.24$, d.f. $=1, P=0.013$. What this means is that men who have been homeless for a longer period of time were often unable or unwilling to hold down a stable job from the very start.

A reluctance to work and a lack of work routines was sometimes manifest from the very outset. This is so in the case of Miroslav (54), a repeat offender who has been sleeping rough for 20 years: "I was locked up for social parasitism [a criminal act under the communist regime] when I was twenty. Then I got a job at Liaz [a defunct Czechoslovak truck maker], where I worked for maybe two years. They sacked me because I stopped showing up for work." Milan (55), who has been sleeping rough for 17 years, was part of a mass layoff: "I used to be a miner working on large machinery. I worked for fifteen years. Then I had problems finding work because they laid us off. I had a series of casual jobs and ended up on the street."

Men who have been sleeping rough for four years or less have mostly held down long-term jobs in the past. They have often then had difficulties in finding other jobs after losing their job or going bankrupt. Libor (50), who has been sleeping rough for one year, found himself in precisely this situation: "Until I was 45 I was a construction technician with the same firm. Then I arranged the papers and went private, but it didn't work out as I had expected and when I was 48 I found myself unemployed. Since then I've had no work. Before becoming homeless I looked for work, but didn't find any."

\section{Marriage and partnerships}

The ability to strike up close relationships with a partner and above all to maintain them is a sign of maturity. This kind of relationship offers support and yet occasionally requires anability to compromise. For a long-term partnership to succeed it needs a sense of responsibility, and this can be a problem for certain individuals. If an adult man is unable to find and live with a partner, it may be the result of an unfavourable combination of personality traits and undesirable habits that are unacceptable to potential partners. This mainly involves drug or alcohol use, as well as an unwillingness to work and provide for the family. There are many reasons why the marriages or partnerships of homeless men end, but alcohol and drugs figure more frequently than in the population at large. Serious money problems or time spent in prison can also cause a relationship to end.

A long-term partnership lasting at least five years is to be found less frequently amongst homeless men than in the gen- eral population. In the case of men who have been sleeping rough for ten years or more, $42 \%$ have maintained such a relationship for at least five years, while a majority (58\%) have been unable to live in a more stable partnership. The situation is similar in the case of men who have been sleeping rough for four years or less, with $52 \%$ having been in a long-term relationship and $48 \%$ having only short-term partners. The difference between the groups is not significant $\left(\chi^{2}=0.01\right.$, d.f. $=1$, $P=0.97)$. The reason is probably the fact that there are more drug addicts and people with mental health issues amongst men who have been sleeping rough for four years or less. Even though they have been sleeping rough for only a short time, men who are drug addicts have not had stable partnerships before becoming homeless. The same is true of men who suffer mental health issues, who are also unable to live in long-term relationships. The situation might be slightly distorted by the fact that some of the men who have only been homeless for a short time have spent several years in prison, which has led to the breakup of their relationship. According to Prudký (2015), $49 \%$ of homeless men are single and $38 \%$ are divorced. Brown et al. (2016) arrived at similar findings, discovering that $46 \%$ of homeless men did not have a stable partner. According to Zugazaga (2004), 80\% of homeless men lived without a partner, most of them single.

The marriages or partnerships of men who have been sleeping rough for ten years or more often ended because of the man's dependence on alcohol or drugs. Zdeněk (51), homeless for ten years, falls into this category: "Yeah, I'd go to work and then be out of it a week. And then, for instance, we went to the pub and I returned home once in three weeks. It was a character defect of mine." Miroslav (55), sleeping rough for 17 years, feels similarly: "I fell in with a certain group about two years previously. I began to drink a bit and became strange. She asked for a divorce. You could say it was because of alcohol."

The situation regarding relationships amongst men who have been homeless for four years or less is more varied. Several lived with their partner for a long time before splitting up. Libor (50) has been sleeping rough for one year: "When I was 25 we started a family, and I got divorced when I was 40 because we no longer had anything in common. I let my ex have the apartment."

A lack of interest in a stable partnership is sometimes associated with drug addiction, as is the case with Peter (37), who has been homeless for four years: "I didn't really have relationships while I was part of the drug scene. I didn't want any. It was the way things happened to work out. I haven't had a long-term relationship. While on drugs I didn't want any relationship, because it would have no future."

\section{Parenthood}

Homeless men often lack a suitable model of parental behaviour. They themselves tend to be poor fathers or do not have any children. Half the homeless men we spoke to are childless, and $40 \%$ are fathers but admit that they do not see their children or pay alimony. Prudký (2015) states that 57\% of homeless men have no children, and we can confirm that figure on the basis of our own research. Of men who have been sleeping rough for ten years or longer, $62 \%$ are childless. This figure is $46 \%$ in the case of those who have been homeless for four years or less. If our respondents have children, they tend not to look after them (38\% of those sleeping rough for ten years or more and $27 \%$ of those homeless for four years or less). The difference between the groups is statistically significant $\left(\chi^{2}=\right.$ 8.96 , d.f. $=2, P=0.011$ ) . In general we can say that when a person finds himself homeless early in life, and remains so for a longer period of time, the likelihood increases that he will 
not have children and that if he does have them he does not look after them.

Men who have been sleeping rough for a shorter period of time are more often in contact with their children and at least make a minimum contribution towards their upkeep. Roman (46) has been sleeping rough for four years: "I get on fine with my sons, we keep in touch over the internet. They know I'm homeless and regard it as normal. I pay alimony of CZK 1,000 [EUR 40]. That's what I make doing this casual work, because I don't want to become completely cut off." Roman spent his childhood in a functional family and only finished up on the streets later in life.

Most men who have been sleeping rough for ten years and more do not look after their children. Most have no idea what they are up to or where they are. Leon (38), a repeat offender who has been sleeping rough for 21 years, has no interest in his children: "I have a son and a daughter. They're with foster parents. I couldn't tell you when they were born exactly, though I know the girl was born in May 2000. That was with my ex-wife. I only really regret the fact that they took my son away from me. They were just waiting for me to make another mistake and then they put my boy directly into foster care."

\section{Ways in which homeless men support themselves}

Our respondents' choice of a particular way of supporting themselves depends on the willingness of the individual to transcend social rules and steal, or accept the humiliation that accompanies the practice of begging.

\section{Begging and scrounging}

Various different studies have shown that $20-60 \%$ of homeless people are involved in begging (Booth, 2005; Garibaldi et al., 2005; Mallett et al., 2004; Vágnerová et al., 2013). The majority of middle-aged homeless men (81\%) who have been sleeping rough for ten years or more admit to begging and scrounging. This figure is only $55 \%$ of those sleeping rough for four years or less. The difference between the two groups is statistically significant $\left(\chi^{2}=3.997\right.$, d.f. $\left.=1, P=0.046\right)$. This means that a willingness to engage in begging can be interpreted as a signal of greater identification with homelessness, and that this relates to the period of time spent on the street. Lee and Farrell (2003) arrived at the same conclusions, namely that a tendency to beg increases with age and the period of time spent homeless.

For some homeless men, begging is the standard way to acquire what they need. For others, it is something they only do in an emergency or when they have overcome their inner barriers by means of alcohol. Simply cadging things is more acceptable to many homeless people than begging, which they regard as more humiliating. The longer a man has been sleeping rough, the more frequently he begs or cadges. Josef (52) has been homeless for 15 years: "I cadge things. If I need cigarettes then I ask someone if they have any. Or I might ask: 'Have you got a bit of spare change?' I don't steal." Dušan (40), homeless for 19 years, also regards cadging items as a normal way of eking out a living, even though he has been issued with repeated fines for doing it: "I've been getting by by scrounging since last August... Scrounging is ok. In one night over the weekend I'll make 700 crowns [EUR 28]. I buy food from a Vietnamese shop using the money I've scrounged."

Men who have been sleeping rough for four years or less often regard begging and scrounging as unacceptable. In general, people with secondary school and sometimes even university education, and who have enjoyed a reasonable status in society at least for a while, share this opinion. For instance, Ladislav (52), who has a secondary school education and has only been sleeping rough for two years, even regards selling Nový Prostor [a magazine sold by homeless people] as a concealed form of begging: "I didn't want to sink to the level of begging. I kind of liked selling Nový Prostor because I was amongst people. To be honest, it's legalised begging, but there is a certain dignity to it and people are sympathetic to the sellers."

\section{Theft}

Various different studies show that between $20 \%$ and $60 \%$ of homeless people steal (Mallett et al., 2004; Whitbeck, 2009). According to a study by Garibaldi et al., $17.5 \%$ of homeless people under the age of 50 steal, and older people less often (only $5 \%$ ). In our cohort of middle-aged men sleeping rough, $17 \%$ who have been homeless for ten years and more admitted to stealing as a source of income, but only $9 \%$ (two members of the cohort) of those sleeping rough for four years or less admitted to doing so. The latter group involves men who, though homeless for a relatively short time, had previously spent several years in prison for burglary. The difference between the two groups is not statistically significant $\left(\chi^{2}=0.78\right)$.

Some men resorted to stealing at the start of their homeless life because of hunger, until they learned that they could get a meal at a charity or scavenge for food in skips. When they are hungry, many of those still steal occasionally. Jiří (48) has been sleeping rough for 17 years: "When I'm hungry I walk into a shop and steal some food. I only steal when I'm hungry. Charities hand out food too, but not all the time. When you run out of money, what choice have you got?"

Homeless people addicted to drugs often steal. Zdeněk (47) has been sleeping rough for 20 years: "Whenever there was nothing to eat, I'd keep myself alive by stealing. I used to steal on a Saturday and Sunday on Národní třida, usually while high, and I used to have fun doing so. Maybe five times I exchanged stolen chocolates for drugs."

\section{Alcohol}

Alcohol abuse is a common cause of homelessness and sometimes a consequence thereof (Caton et al., 2006; McVicar et al., 2015; Stergiopoulos and Herrmann, 2003). Various studies show that between $40 \%$ and $70 \%$ of homeless people drink to excess (Amato and MacDonald, 2011; Anderson and Christian, 2003; Ball et al., 2005; Brown et al., 2016; Caton et al., 2006; Clark et al., 2011; Didenko and Pankratz, 2007; Dietz, 2009; Fazel et al., 2008; Koegel, 2004; Levinson, 2004; Zugazaga, 2004). Only $24 \%$ of a group of young Prague homeless people had this problem, while $65 \%$ of middle-aged homeless men drank to excess (Vágnerová et al., 2013).

In our cohort, $62 \%$ of the middle-aged men who had been sleeping rough for ten years or more admitted to being dependent on alcohol, and $14 \%$ drank frequently but were not dependent (with $24 \%$ of the latter group drinking only infrequently). However, in the group of men who have been homeless for four years or less, only $29 \%$ are dependent (14\% drink frequently but are not dependent, and 57\% drink only rarely or not at all). The difference between the two groups is statistically significant $\left(\chi^{2}=6.727\right.$, d.f. $=2, P=0.035$. There is a direct relationship between drinking alcohol and homelessness: there is a greater risk of becoming homeless amongst people who drink excessively, and there is a greater risk of drinking to excess amongst homeless people. Shelton et al. (2009) arrived at the same conclusions. Men who have been sleeping rough for ten years or more have usually been drinking since they were young: $72 \%$ of them began to drink seriously between the ages of 18 and 25 . In the case of men who have been living on the street for four years or less, the consumption of alcohol 
increased between the ages of 30 and 40 . This means that the earlier someone begins to drink to excess, the earlier they may become homeless and the longer they may remain so.

Alcohol abuse is often the reason homeless people lose their jobs. This is so in the case of Jirka (47), who has been sleeping rough for 20 years: "I fell in with a crowd of older boys who taught me how to drink. When I was 12 I got drunk and since then I've been a regular drinker. At the age of 27 I started going to a charity because I was spending my money on booze. I overdid it with the booze and so they booted me out of work, and since my accommodation was linked to my job, I lost both."

Men who have been sleeping rough for four years or less are able to limit their drinking earlier, generally in order to maintain a minimum standard of living: $60 \%$ of them now drink less or not at all. Vlastimil (46) has been homeless for three years: "I no longer drink, because if I did they wouldn't let me into the doss-house and these day I prefer to get a good night's sleep."

\section{Use of illicit substances}

Drug taking and the ease with which a person becomes addicted is another frequent cause of sleeping rough and the chronification of homelessness (McVicar et al., 2015). Depending on the research findings, the prevalence of drug users amongst homeless people is anything between $35 \%$ and $75 \%$ (Amato and MacDonald, 2011; Ball et al., 2005; Brown et al., 2016; Caton et al., 2005, 2007; Zugazaga, 2004). According to Grenier et al. (2013), as many as $83 \%$ of the long-term homeless take drugs. Drugs are a standard part of life for the homeless community (Johnson and Chamerlain, 2008; Rhoades et al., 2011; Stein et al., 2008). Johnson and Chamberlain (2008) found that a third of homeless people who are addicted to drugs abused them prior to becoming homeless, while two thirds only began to use them upon starting to sleep rough.

In our sample, only $20 \%$ of middle-aged homeless men took drugs. $41 \%$ of men who have been sleeping rough for ten years and more take drugs at least occasionally, while this figure is only $9 \%$ in the case of men who have been on the street for four years or less. The difference between the groups is statistically significant $\left(\chi^{2}=6.74\right.$, d.f. $\left.=2, P=0.034\right)$. We may therefore conclude that the use of drugs leads to homelessness earlier and to an increased risk of the chronicity of homelessness. Men who have been sleeping rough for ten years and more usually began to take drugs prior to becoming homeless when they were aged between 15 and 25, while only $18 \%$ actually began to take drugs on the street. Middle-aged men living on the street for four years and less all began using drugs long before.

Men who are currently homeless began to experiment with drugs while relatively young. Václav (38) has been sleeping rough for 13 years: "I started to take drugs when I was 18 or 19. For a year as an apprentice I was surrounded by drugs. And then one time I decided to try them and unfortunately it began to get a grip on me. I began with pervitin [methamphetamines], but after six months I moved onto heroin. Whenever I had any money I blew it all on drugs. I've been to a psychologist loads of times. I've been in rehab, but I never completed the therapy."

\section{Criminal activities}

A high percentage of the homeless are men who arrived on the street from prison. As a consequence of their criminal activities they lost their home and accommodation and upon being released have nowhere to return to. Criminal activity is higher amongst the homeless than amongst the general population. Sleeping rough increases the risk of committing criminal activities, usually involving property. The reasons are manifold and include material necessity, a reduced ability to regulate a person's own behaviour, and also the fact that there is less fear of condemnation from other people in the homeless community. For most homeless people the thought of prison holds no threat since they would enjoy greater comfort than they do on the street. For many, moving between the street and prison is commonplace (Mabhala et al., 2016). Studies put the number of homeless people who have been in prison at least once between 30\% and 60\% (Goering et al., 2002; Fischer, 2004; Caton et al., 2005, 2007; Shelton et al., 2009; Štěchová, 2009; Brown et al., 2016). According to a study by Zugazaga (2004) this figure is as high as $82 \%$.

In the group of middle-aged homeless men that we examined who have been sleeping rough for ten years or more, $72 \%$ have spent time in prison, while this figure is only $45.5 \%$ in the case of men who have been homeless for four year or less. The difference between these groups is statistically significant $\left(\chi^{2}=3.81\right.$, d.f. $\left.=1, P=0.05\right)$. Most of the crimes committed by these men involved property and to a lesser extent violence. It is clear that criminal activities and a period of time spent in prison can result in homelessness earlier in life and is a significant factor for chronicity of homelessness.

Most homeless people became involved in criminal activities as young people. This was so in the case of Jaroslav (50), a repeat offender, who has been sleeping rough for two years: "As soon as I left the children's home they locked me up for theft... I've spent around 12 or 13 years in prison. The last time I was in for four years. I worked for around a year in a factory, but I got fed up and stopped working. I started to think about how to earn money without having to work. So I began to steal things and again I was put in prison for a year or so. When I got out, I got myself together and then started stealing again. Immediately they locked me up. I didn't even bother trying to find work." A shorter time spent sleeping rough does not always have to mean that this is a less serious case of homelessness. It is often the case that the man in question has simply spent a significant part of his life in prison.

Criminal activity often goes hand in hand with alcohol abuse, which lowers inhibitions. It was under the influence of alcohol that Bagal (52), who has been sleeping rough for 20 years, committed a crime: "I had been put in prison for three years for burglary with assault... I got drunk and don't know what came over me. And then I was in prison in Ostrov nad Ohři and when I was released I came to Prague. I was only inside for six months that time for a small burglary, I can't even remember the details. I was back in prison about two years later. That was in Prague, where I was setting fire to wire [in order to get at the copper] and they caught me. I was sentenced to five years and told to stay away from Prague. I've always been free for a while and then back in prison for a year." Bagal's conduct was not only influenced by alcohol, but by his mental health problems too.

Sleeping rough can reinforce a tendency to steal. This is what Jiří, who has been homeless for 17 years, believes: "Homelessness encourages crime because if you lack something, then you steal it. You have no other option, because you can't earn the money, go to an agency or whatever. If you're hungry and you have nothing to eat then you simply steal something..."

Men who have been living on the street for a long time and have been to prison several times are not afraid of it. Gonzales (50) has been homeless for ten years: "I can't say it bothers me. If it comes to it I'll break things, stand up and go to prison. You're fed three times a day, you have television, a gym... What's not to like?"

\section{Psychological disorders and mental health issues}

Studies show that personality disorders and mental health issues can increase the risk of homelessness. The reasons 
include an inability to cope with the demands of everyday life, increased vulnerability, an inability to cope with what for others are normal burdens, a lack of money, and a lack of support from family and friends. The frequency of personality disorders and mental health issues is higher amongst the homeless than in the population at large. Sometimes psychological problems only occur during a homeless life and are brought on by the added stress (Early, 2005). Various studies have shown that the number of such people within the homeless community is between 25\% and 45\% (Breakey, 2004; Brown et al., 2016; Caton et al., 2005; Johnson and Chamberlain, 2011; Shelton et al., 2009; Štěchová, 2008; Sullivan et al., 2000). The study conducted by Johnson and Chamberlain (2011) concluded that $15 \%$ of homeless people had already suffered psychological problems before becoming homeless, and a further $16 \%$ developed problems later. Studies have also shown that anything between $25 \%$ and $50 \%$ of homeless people experience depression (Garibaldi et al., 2005; Goering et al., 2002; Shelton et al., 2009). The differences reported might be related to the different criteria used by researchers. However, there is no doubt that homeless people suffer depression relatively often. A dual diagnosis may often be involved in which depression is combined with drug or alcohol abuse.

Psychological problems are experienced by $45.5 \%$ of men who have been sleeping rough for four years or less, and $48 \%$ of men who have been in the same situation for ten years or more. However, this difference is not statistically significant $\left(\chi^{2}=0.04\right)$. Also of interest is what disorder or mental health issue such people suffer from. In general we can say that personality disorders and mental health issues represent a burden that increase the risk of someone finding themselves homeless. These problems can present themselves at any age, both prior to a person becoming homeless and while homeless. There are many reasons why homeless people suffer depression, which may be primary or secondary. Treatment in these cases is more difficult.

Mental health issues may have led to a loss of employment and subsequent homelessness, especially if the sick person has no relatives that could help him or is no longer in touch with them. This was so in the case of Ivo (41), who has been sleeping rough for a year and has schizoaffective disorder: "After school I joined a construction company and worked there for two years... When I started having these attacks, it was a problem finding work. All I could find was casual work, and that's how I found myself living on the street. For a year and a half I lived in a shelter. Then I was offered supported housing, but I only stayed in it for two months and then left. I wasn't happy there. I received benefits for psychiatric problems... My parents are both dead and my brother and sister gave up on me years ago."

Homeless men often suffer from depression that can lead to suicidal behaviour. This is more often so in the case of men who have been sleeping rough for ten years or more (38\%) than men in the same situation for four years or less (23\%). Depression is often linked to the excessive consumption of alcohol and drug use, i.e. a dual diagnosis is often involved. For instance, Oldřich (53), who drinks heavily and takes drugs and has been sleeping rough for twenty years, suffers depression and has suicidal tendencies: "I wanted to throw myself under a tram, but the police caught me in time and took me to Berkovice [a psychiatric hospital]. Sometimes I see no point in living, for instance when I'm outside, no money and so on. I get nothing out of the world or people. It's a kind of resentment, and so I drank and took drugs because I'm stupid... I didn't want to carry on living because I had no-one and nothing. I didn't want to live; I was completely apathetic. I slashed my wrists while in prison in Bory. I had had enough, so I cut my wrists."

Some of our cohort suffered from depression even prior to becoming homeless. This was so in the case of Libor (50), who has been sleeping rough for one year, though he has long had a problem with alcohol: "I've had depression all my life, every autumn. To be honest, sometimes you feel like jumping off a bridge. You're fed up, you haven't slept for several days, maybe you're not eating but chucking food away. You have no idea what you're supposed to do. It's pretty obvious that under these circumstances you're going to be depressed."

\section{Discussion}

The process of becoming homeless takes many different forms. There may be a variety of causes that subsequently intensify the risk of the chronicity of homelessness. Homelessness is often the result of a combination of endogenous and exogenous factors involving high-risk personality traits, insufficient abilities and skills, unfavourable life circumstances, and the lack of a social background that provides the necessary support (Anderson and Christian, 2003; Grenier et al., 2013; Štěchová, 2009). The accumulation of these factors is manifest in behaviour that accelerates social deterioration (e.g. alcohol abuse and drug use or criminal activities).

Men who have been sleeping rough for more than ten years had problems adapting as children. They grew up in a problematic family or in an institution and acquired only a rudimentary education. From the start they had problems at work, found it difficult to apply themselves and did not last long in employment. They tend to have high-risk personality traits and often a personality disorder (which one of the parents also probably had). Early in life they had problems with alcohol or drugs and their relationships (supposing they had any) always ended. If they have children, they do not look after them. They are reckless even when it comes to laws and often commit crime. They usually ended up on the street in their thirties. Prudký (2015) calls this the long trajectory, because it takes the form of a lifelong path. Such people usually lack motivation and the will to make any fundamental change to their lives. They identify with the homeless community and have no other contacts.

Men who have been sleeping rough for four years or less form two subgroups. There are those who had a normal childhood, attended school and found work. They started a family but began to drink, and as a consequence lost their family and their job. They end up on the street between the ages of 35 and 40. And then there are men who become homeless after the age of 40 because of an inability to cope with a difficult situation, e.g. divorce or indebtedness. They are not dependent on alcohol or drugs and do not have a criminal record. The life stories correspond to the findings of McDonald et al. (2007), namely that if a man becomes homeless after he is 40 , there is a $70 \%$ likelihood that the cause is the breakup of a family or loss of employment. Prudký (2015) calls this variant the short trajectory. Such people can be offered effective assistance from the social services to return to mainstream society - because they have not yet fully self-identified with the homeless community and most of them have retained the necessary abilities and skills. 


\section{Conclusions}

The length of time a person has been homeless is an important factor in respect of social intervention. It is clear that the longer a person is homeless, the worse their chances of being reintegrated into mainstream society. As Štěchová (2008; 2009) says, motivated clients can be reintegrated after a maximum of five years on the street as long as they are not dependent on drugs or alcohol and are not repeat offenders. Longer than five years and they are no longer able to cope with such a fundamental change. As far as homeless people who are alco- hol or drug dependent are concerned, standard social work has no great effect. The chronic homeless need to have their basic requirements met and the conditions created for acceptable survival.

\section{Acknowledgements}

This study was supported by the Czech Science Foundation, project \# P407/16/11776S Psychosocial analysis of middle-aged homeless in Prague.

\section{Conflict of interests}

The authors have no conflict of interests to declare.

\section{Jak délka doby strávené na ulici ovlivňuje adaptaci na bezdomovectví}

\section{Souhrn}

Úvod: Délka času stráveného na ulici ovlivňuje míru přizpůsobení se bezdomovectví. V průběhu let strávených na ulici lidé bez domova postupně ztrácejí schopnost řídit svůj život a jejich návrat do společnosti je stále méně pravděpodobný.

Cíl: Cílem studie bylo zjistit, zda a jak se liší muži, kteří žijí na ulici déle než deset let, od těch, kteří byli bez domova po dobu čtyř let nebo méně.

Metodika: Výzkum byl založen na narativní analýze hloubkových rozhovorů zaměřených na celý životní příběh respondenta, tj. na jejich dětství, dospívání a období dospělosti předcházející bezdomovectví. Zkoumanou skupinu tvořilo 51 mužů bez domova ve věku 37-54 let.

Výsledky: Muži, kteř́ žili na ulici déle než deset let, vyrůstali v problematické rodině nebo v ústavním zařízení a získali pouze základní vzdělání. Od začátku měli problémy v práci. Mají tendenci mít vysoce rizikové osobnostní rysy a často mají poruchu osobnosti. Problémy s alkoholem nebo drogami mají od rané dospělosti. Jsou lehkomyslní, často se dostávají do střetu se zákonem a dopouštějí se trestných činů.

Závěr: Délka času, po kterou člověk žije na ulici, je důležitým faktorem ve vztahu k sociální prevenci. Je zřejmé, že čím déle je člověk bezdomovcem, tím horší jsou jeho šance na opětovné začlenění do běžné společnosti.

Klíčová slova: běh života; lidé bez domova; narativní analýza; rizikové faktory; sociální přizpůsobivost

\section{References}

1. Amato F, MacDonald J (2011). Examining risk factors for homeless men: Gender role conflict, help-seeking behaviors, substance abuse and violence. Journal of Men's Studies 19(3): 227-235. DOI: 10.3149/jms.1903.227.

2. Amore K, Baker M, Howden-Chapman P (2011). The ETHOS definition and classification of homelessness: An analysis. European Journal of Homelessness 5(2): 19-37.

3. Anderson I, Christian J (2003). Causes of homelessness in the UK: Dynamic analysis. Journal of Community and Applied Social Psychology 13: 105-118. DOI: 10.1002/casp.714.

4. Auerswald CL, Eyre SL (2002). Youth homelessness in San Francisco: A lifecycle approach. Social Science and Medicine 54(10): 1497-1512. DOI: 10.1016/S0277-9536(01)00128-9.

5. Ball SA, Cobb-Richardson P, Connolly AJ, Bujosa CT, O'Neall TW (2005). Substance abuse and personality disorders in homeless drop-in center clients: symptom severity and psychotherapy retention in a randomized clinical trial. Compr Psychiatry 46(5): 371-379. DOI: 10.1016/j.comppsych.2004.11.003.

6. Booth S (2005). Eating rough: food sources and acquisition practices of homeless young people in Adelaide, South Australia. Public Heath Nutr 9(2): 212-218. DOI: 10.1079/phn2005848.

7. Boydell KM, Goering P, Morrell-Bellai TL (2000). Narratives of identity: Representation of self in people who are homeless. Qual Health Res 10(1): 26-38. DOI: $10.1177 / 104973200129118228$.

8. Breakey WR (2004). Mental illness and health. In: Levinson D (ed.), Encyclopaedia of homelessness. Sage publ., Thousand Oaks, London.

9. Brown RT, Goodman D, Tieu L, Ponath C, Kushel M (2016). Pathways to homelessness among older homeless adult: Results from the HOPE HOME study. PloS ONE 11(5): e0155065. DOI: 10.1371/journal.pone.0155065.

10. Caton CL, Dominguez B, Schanzer B, Hasin DS, Shrout PE, Felix A, et al. (2005). Risk factors for long-term homelessness: Findings from a longitudinal study of first-time homeless single adults. Am J Public Health 95: 1753-1759. DOI: 10.2105/ AJPH.2005.063321.

11. Caton CL, Wilkins C, Anderson J (2007). People who experience long-term homelessness. Characteristics and intervention. National Symposium on Homelessness Research.

12. Cauce AM, Paradise M, Ginzler JA, Embry L, Morgan CJ, Lohr Y, Theofelis J (2000). The characteristics and mental health of homeless adolescents: Age and gender differences. Journal of Emotional and Behavioral Disorders 8(4): 230-239. DOI: 10.1177/106342660000800403.

13. Clark C, Young S, Barrett B (2011). A transactional model of homelessness and alcoholism? Developing solutions for complex problems. Louis de la Parte Florida Mental Health Institute, $11 / 15$

14. Didenko E, Pankratz N (2007). Substance use. Pathways to homelessness? Or a way of adapting to street life? Visions: BC's Mental Health and Addictions Journal 4(1): 9-10.

15. Dietz TL (2009). Drug and alcohol use among homeless older adults. Journal of Applied Gerontology 28: 235-255. DOI: $10.1177 / 0733464808326006$.

16. Early DW (2005). An empirical investigation of the determinants of street homelessness. Journal of Housing Economics 14(1): 27-47. DOI: 10.1016/j.jhe.2005.03.001.

17. Farrington A, Robinson WP (1999). Homelessness and strategies of identity maintenance: A participant observation study. Journal of Community and Applied Social Psychology 9(3): 175-194. DOI: 10.1002/(SICI)10991298(199905/06)9:3<175::AID-CASP497>3.0.CO;2-R. 
18. Fazel S, Khosla V, Doll H, Geddes J (2008). The prevalence of mental disorders among the homeless in western countries: Systematic review and meta-regression analysis. PloS Med 5(12): e225. DOI. 10.1371/journal.pmed.0050225.

19. Fergusson KM (2009). Exploring family environment characteristics and multiple abuse experiences among homeless youth. J InterpersViolence 24(11): 1875-1891. DOI: $10.1177 / 0886260508325490$.

20. Fischer PJ (2004). Criminal activity and policing. In: Levinson D (Ed.). Encyclopaedia of homelessness. Sage publ., Thousand Oaks, London.

21. Garibaldi B, Conde-Martel A, O’Toole TP (2005). Self-reported comorbidities, perceived needs, and sources for usual care for older and younger homeless adults. J Gen Intern Med 20(8): 726-730. DOI: 10.1111/j.1525-1497.2005.0142.x.

22. Goering P, Tolomiczenko G, Sheldon T, Boydell K, Wasylenki D (2002). Characteristics of persons who are homeless for the first time. Psychiatr Serv 53(11): 1472-1474. DOI: 10.1176/appi. ps.53.11.1472.

23. Grenier A, Barken R, Sussman T, Rothwell D, Lavoie JP (2013). A report on aging and homelessness. SSHRS project, Gilbrea Centre for Studies in Aging.

24. Janebová R (1999). Proces vzniku a stadia bezdomovectví. Sociální práce 4: 27-28.

25. Johnson G, Chamberlain C (2008). From youth to adult homelessness. Australian Journal of Social Issuess, 43 563-582. DOI: 10.1002/j.1839-4655.2008.tb00119.x.

26. Johnson G, Chamberlain C (2011). Are the homeless mentally ill? American Journal of Social Issues, 46(1): 29-48. DOI: 10.1002/j.1839-4655.2011.tb00204.x.

27. Koegel P (2004). Homelessness. In: Levinson D (Ed.). Encyclopaedia of Homelessness. London, Sage, 124-127.

28. Lee BA, Farrell CR (2003). Buddy, can you spare a dime? Homelessness, panhandling, and the public. Urban Affairs Review 38(3): 299-324. DOI: 10.1177/1078087402238804

29. Levinson D (Ed.) (2004): Encyclopaedia of homelessness. Sage Publications, Thousand Oaks, London.

30. Mabhala MA, Ellahi B, Massey A, Kingston P (2016). Understanding the determinants of homelessness through examining the life stories of homeless people and those who work with them: A qualitative research protocol. Diversity and Equality in Health and Care 13: 284-289. DOI: 10.21767/20495471.100064.

31. Mallett S, Rosenthal D, Myers P, Milburn N (2004). Practising homelessness: a typology approach to young people's daily routines. Journal of Adolescence 27(3): 337-349. DOI: 10.1016/j.adolescence.2003.11.014.

32. McDonald L, Dergal J, Cleghorn L (2007). Living on the margins. Older homeless adults in Toronto. J Gerontol Soc Work 49(1-2): 19-46. DOI: 10.1300/J083v49n01_02.
33. McVicar D, Moschion J, van Ours JC (2015). From substance use to homelessness or vice versa? Soc Sci Med 136-137, 89-98. DOI: 10.1016/socscimed.2015.05.005.

34. Osborn M, Smith JA (2008). Interpretative phenomenological analysis. In: Smith JA (Ed.). Qualitative Psychology. A Practical guide to method. London, Sage.

35. Prudký L (2015). Humanistický a otevřený přístup jako jediný pramen řešení bezdomovectví. Konsenzuální konference o bezdomovectví v České republice. Sborník, Ministerstvo práce a sociálních věcí.

36. Rank MR, Williams JH (2010). A life course approach to understanding poverty among older American adults. Fam Soc 91(4): 337-341. DOI: 10.1606/1044-3894.4032.

37. Rhoades H, Wenzel SL, Golinelli D, Tucker JS, Kennedy DP, Green HD, Zhou A (2011). The social context of homeless men's substance use. Drug Alcohol Depend 118(2-3): 320-325. DOI: 10.1016/j.drugalcdep.2011.04.011.

38. Shelton KH, Taylor OJ, Bonner A, van den Bree M (2009). Risk factors for homelessness: Evidence from a population-based study. Psychiatr Serv 60(4): 465-472. DOI: 10.1176/appi. ps.60.4.465.

39. Štěchová M (2008). Bezdomovectví jako extrémní forma sociálního vyloučení. In: Štěchová M, Luptáková M, Kopoldová B. Bezdomovectví a bezdomovci z pohledu kriminologie. Praha: IKSP.

40. Štěchová M (2009). Bezdomovci a vybrané sociálně patologické jevy. Kriminalistika 4: 265-277.

41. Stein JA, Dixon EL, Nyamathi AM (2008). Effects of psychosocial and situational variables on substance abuse among homeless adults. Psychol Addict Behav 22(3): 410-416. DOI: 10.1037/0893-164X.22.3.410.

42. Stergiopoulos V, Herrmann N (2003). Old and homeless: A review and survey of older adults who use shelters in a Urban setting. Can J Psychiatry 48(6): 374-380. DOI: $10.1177 / 070674370304800603$.

43. Sullivan G, Burnam A, Koegel P (2000). Pathways to homelessness among the mentally ill. Soc Psychiatry Psychiatr Epidemiol 35(10): 444-450. DOI: 10.1007/s001270050262.

44. Tyler KA (2006). A qualitative study of early family histories and transitions of homeless youth. J Interpers Violence 21(10): 1385-1393. DOI: 10.1177/0886260506291650.

45. Vágnerová M, Csémy L, Marek J (2013). Bezdomovectví jako alternativní existence mladých lidí. Praha: Karolinum.

46. Whitbeck LB (2009). Mental health and emerging adulthood among homeless young people. New York, Hove, Psychology Press, Taylor and Francis Group.

47. Zugazaga C (2004). Stressful life event experiences of homeless adults: A comparison of single men, single women, and women with children. Journal of Community Psychology 32(6): 643-654. DOI: 10.1002/jcop.20025. 